\title{
Current status and strategies for viral hepatitis control in Korea
}

\author{
Dong Hyun Sinn', Eun Ju Cho², Ji Hoon Kim³, Do Young Kim, Yoon Jun Kim², and Moon Seok Choi \\ 'Department of Medicine, Samsung Medical Center, Sungkyunkwan University School of Medicine; ${ }^{2}$ Department of Internal Medicine \\ and Liver Research Institute, Seoul National University Hospital, Seoul National University College of Medicine; ${ }^{3}$ Department of \\ Internal medicine, Korea University Guro Hospital; ${ }^{4}$ Department of Internal Medicine, Yonsei University College of Medicine, Seoul, \\ Korea
}

Viral hepatitis is one of major global health challenges with increasing disease burden worldwide. Hepatitis B virus and hepatitis $C$ virus infections are major causes of chronic liver diseases. They can lead to cirrhosis, hepatocellular carcinoma, and death in significant portion of affected people. Transmission of hepatitis B virus can be blocked by vaccination. Progression of hepatitis $B$ virus-related liver diseases can be prevented by long-term viral suppression with effective drugs. Although vaccine for hepatitis $C$ virus is currently unavailable, hepatitis $C$ virus infection can be eradicated by oral direct antiviral agents. To eliminate viral hepatitis, World Health Organization (WHO) has urged countries to develop national goals and targets through reducing $90 \%$ of new infections and providing universal access to key treatment services up to $80 \%$. This can lead to $65 \%$ reduction of viral hepatitis-related mortality. Here, we discuss some key features of viral hepatitis, strategies to control viral hepatitis suggested by WHO, and current status and strategies for viral hepatitis control in South Korea. To achieve the goal of viral hepatitis elimination by 2030 in South Korea, an independent 'viral hepatitis sector' in Centers for Disease Control \& Prevention (CDC) needs to be established to organize and execute comprehensive strategy for the management of viral hepatitis in South Korea. (Clin Mol Hepatol 2017;23:189-195)

Keywords: Viral hepatitis; Hepatitis B; Hepatitis C; Hepatitis A; Korea

\section{INTRODUCTION}

Viral hepatitis is liver inflammation due to viral infection. Several viruses can cause liver inflammation, including hepatotropic viruses, cytomegalovirus, Epstein-Barr virus, herpes simplex virus, and so on. The most common causes of viral hepatitis are hepatotropic viruses: hepatitis A virus (HAV), hepatitis B virus (HBV), hepatitis $C$ virus (HCV), hepatitis D virus (HDV), and hepatitis $E$ virus (HEV). These five hepatitis viruses are very different in their modes of transmission and health outcomes (Table 1). Viral hepatitis, particularly hepatitis $B$ and hepatitis $C$, has been silent killer for decades across all global regions.' An estimated 1.4 million deaths per year are caused by acute infection and hepatitis-related liver cancer and cirrhosis. Of those deaths, approximately $47 \%$ are attributable to $\mathrm{HBV}, 48 \%$ are due to $\mathrm{HCV}$, and the remainder is due to HAV and HEV. Worldwide, approximately 240 million people have chronic HBV infections and 130-150 million have chronic HCV infections. Unlike most other communicable diseas-

\section{Abbreviations:}

HAV, hepatitis A virus; HBV, hepatitis B virus; $H C V$, hepatitis C virus; HDV, hepatitis D virus; HEV, hepatitis E virus; $P C R$, polymerase chain reaction; WHO, World Health Organization

\section{Corresponding author: Moon Seok Choi}

Department of Medicine, Samsung Medical Center, Sungkyunkwan University School of Medicine, 81 Irwon-ro, Gangnam-gu, Seoul 06351, Korea

Tel: +82-2-3410-3409, Fax: +82-2-3410-6983

E-mail:drmschoi@gmail.com

http://orcid.org/0000-0002-9690-9301

Received : Jun. 5, 2017/ Accepted : Jun. 16, 2017

Copyright ( 2017 by The Korean Association for the Study of the Liver

This is an Open Access article distributed under the terms of the Creative Commons Attribution Non-Commercial License (http://creativecommons.org/licenses/by-nc/3.0/) which permits unrestricted non-commercial use, distribution, and reproduction in any medium, provided the original work is properly cited. 
Table 1. Characteristics of hepatotrophic viruses

\begin{tabular}{|c|c|c|c|c|c|}
\hline & Hepatitis A virus & Hepatitis B virus & Hepatitis C virus & Hepatitis D virus & Hepatitis E virus \\
\hline Genome & RNA & DNA & RNA & RNA & RNA \\
\hline Family & Picorna viriade & Hepadna viridae & Flavi viridae & Deltavirus & Hepa viriade \\
\hline Incubation (d) & $15-45$ & $30-180$ & $15-150$ & $30-180$ & $15-60$ \\
\hline Transmission & Fecal to Oral & Blood & Blood & Blood & Fecal to Oral \\
\hline Chronicity & No & Yes & Yes & Yes & Rare \\
\hline Prevention & Vaccine & Vaccine & No & HBV vaccine & Vaccine $^{*}$ \\
\hline Antivirals drugs & No & Yes & Yes & Yes & No \\
\hline
\end{tabular}

Approved in China only.

es, absolute burden and relative rank of viral hepatitis were increased between 1990 and 2013. ${ }^{2}$ Without expanded and accelerated response, viral hepatitis will be a huge burden for the next 40-50 years, with cumulative deaths estimated to be approximately 20 million between 2015 and 2030. ${ }^{3}$ Viral hepatitis is gaining greater attention nowadays with some vital progress made.' Transmission of hepatitis B virus can be blocked by vaccination. Progression of hepatitis B virus-related liver disease can be prevented by long-term viral suppression with effective drugs. ${ }^{4}$ Oral direct antiviral agents against hepatitis $C$ virus have been developed. These drugs are highly effective in eradicating hepatitis $C$ virus and well-tolerated by patients. ${ }^{5}$ During World Health Assembly held in May 2016, World Health Organization (WHO)'s Global Strategy for Viral Hepatitis was approved. It elevated hepatitis to a higher priority with a goal to eliminate viral hepatitis as a public health threat by 2030. Its vision is that viral hepatitis transmission is halted in the world and everyone living with viral hepatitis has access to safe, affordable, and effective care and treatment. $^{3}$

\section{VIRAL HEPATITIS: HEPATITIS A}

Hepatitis A is a liver disease caused by HAV. ${ }^{6}$ Hepatitis A is primarily spread when an uninfected (and unvaccinated) person ingests food or water that is contaminated with feces of an infected person. ${ }^{7}$ The disease is closely associated with unsafe water or food, inadequate sanitation, and poor personal hygiene. HAV is one of the most frequent causes of foodborne infections. Epidemics related to contaminated food or water can erupt explosively.

Geographical distribution areas of hepatitis A can be characterized as having high, intermediate, or low levels of HAV infection. ${ }^{7}$ In developing countries with poor sanitary conditions and hygienic practices, most (90\%) children have been infected by HAV before the age of 10 years. Those infected during childhood do not experience any noticeable symptoms. Epidemics are uncommon because older children and adults are generally immune. Symptomatic disease rates in these areas are low and outbreaks are rare. In developing countries, countries with transitional economies, and regions where sanitary conditions are improved, children can often escape infections in early childhood and reach adulthood without immunity. Ironically, improved economic and sanitary conditions may lead to accumulation of adults who have never been infected, and have no immunity. ${ }^{10}$ Higher susceptibility in older age group may lead to higher symptomatic disease rates and large outbreaks in these communities. In developed countries with good sanitary and hygienic conditions, infection rates are low. Disease may occur among adolescents and adults in high-risk groups such as people travelling to areas with high endemicity.

Symptoms of hepatitis A range from mild to severe. Adults have signs and symptoms of illness more often than children. ${ }^{6}$ Severity of the disease and fatal outcomes are higher in older age groups. Hepatitis A infection does not cause chronic liver disease. However, it can cause acute liver failure. Acute hepatitis A can be diagnosed by the detection of hepatitis A virus-specific immunoglobulin $\mathrm{M}$ antibodies in the blood. Those who have recovered from hepatitis $A$ infection and those who are vaccinated will show hepatitis $A$ virus-specific immunoglobulin $G$ antibodies in the blood. There is no specific treatment for hepatitis $A$. Recovery from symptoms following infection may be slow. It may take several weeks or several months. Hepatitis A can be prevented by improving sanitation and food safety. It can also be prevented by immunization. ${ }^{7}$

\section{HEPATITIS B}

Hepatitis B is a liver infection caused by $\mathrm{HBV}^{4}$ It can cause 
chronic infection. It is a major cause of liver cirrhosis and liver cancer for those who are chronically infected. ${ }^{4}$ Hepatitis B prevalence is different according to geographic regions. High rates of chronic infections have been found in sub-Saharan Africa, East Asia, Amazon area, and southern parts of eastern and central Europe. In highly endemic areas, hepatitis B is most commonly spread through mother-to-child transmission. ${ }^{11}$ Chronic infection is very common when infected in infant period or before the age of 5 years. Hepatitis B can also spread through percutaneous or mucosal exposure to infected blood and various body fluids. Transmission of the virus may also occur through sexual contact, reuse of needles and syringes during medical, surgical, and dental procedures, tattooing, or use of razors and similar objects that are contaminated with infected blood. Infection that develops in adulthood can lead to chronic hepatitis in less than $5 \%$ of cases. Most people do not experience any symptoms during the acute infection phase. A small subset of people with acute hepatitis can develop acute liver failure which can lead to death. When it causes chronic liver infection, it can lead to liver cirrhosis and liver cancer. $^{4}$

Hepatitis B can be diagnosed by detecting hepatitis B surface antigen. Acute or chronic infection can be differentiated by performing immunoglobulin antibody to core antigen and hepatitis $B$ e antigen. Virus can be detected by performing polymerase chain reaction ( $P C R$ ). No specific treatment can completely eradicate hepatitis B virus. However, oral nucleos(t)ide analogue has been developed. It can effectively suppress hepatitis B replication. Interferon can also be used to suppress hepatitis B replication in highly selected setting. ${ }^{4}$

Hepatitis B transmission can be prevented by using hepatitis B vaccine. In addition, implementing blood safety strategies, including quality-assured screening of all donated blood and blood components used for transfusion, safe injection practices, and safe sex practices can prevent the transmission of hepatitis B virus. ${ }^{4}$

\section{HEPATITIS C}

Hepatitis C virus causes both acute and chronic infections. ${ }^{5}$ Acute infection is usually asymptomatic. About $15-45 \%$ of infected persons can spontaneously clear the virus within 6 months of infection without any treatment. The remaining $55-85 \%$ of persons will develop chronic HCV infection. Of those with chronic HCV infection, some will develop liver cirrhosis and liver cancer. HCV is found worldwide. The most affected regions are Africa,
Central Asia, and East Asia. Depending on the country, hepatitis $C$ infection can be concentrated in certain populations (for example, among people who inject drugs). HCV is a bloodborne virus. It can be transmitted through contaminated injection equipment, reuse or inadequate sterilization of medical equipment (syringes and needles in healthcare settings), and transfusion of unscreened blood or blood product. HCV can also be transmitted sexually. ${ }^{4}$

$\mathrm{HCV}$ can be confirmed by PCR detection of the virus. As PCR analysis is costly, anti-hepatitis C virus antibody is usually performed to screen those who might have been infected with the virus. Treatment for hepatitis $\mathrm{C}$ is changing rapidly. Recently, direct antiviral agents have been developed. They are highly effective, safe, and better-tolerated by patients. Therapy with direct antiviral agents can cure almost all infected persons in a short (usually 12 weeks) duration. Since there is no vaccine for hepatitis $C$, prevention of HCV infection depends upon reducing the risk of exposure to the virus (in health-care settings, in higher risk populations such as people who inject drugs, or through sexual contact)., ${ }^{5,7}$

\section{HEPATITIS D}

Hepatitis $D$ is a liver disease caused by HDV. ${ }^{7,12}$ HDV requires HBV for its replication. Hence, Hepatitis D infection cannot occur in the absence of HBV. Coinfection or super infection of HDV with HBV causes more severe disease than HBV mono-infection. It is estimated that $5 \%$ of hepatitis B surface antigen positive people are coinfected with HDV globally. Distribution of HDV is worldwide. However, its prevalence is different according to region. High-prevalence areas include the Mediterranean, Middle East, Pakistan, Central Asia, and Northern Asia. Its prevalence is low in North America, Northern Europe, South Africa, and East Asia including South Korea. ${ }^{13}$

HDV can be diagnosed by finding antibody against HDV. It can be confirmed by detection of HDV RNA in serum. However, HDV diagnostics are not widely available. There is no standardization for HDV RNA assay. There is no specific treatment for acute or chronic HDV infection either. Persistent HDV replication is the most important predictor of mortality and the need for antiviral therapy. Pegylated interferon alpha is the only drug effective against HDV. Antiviral nucleotide analogues for HBV have no or limited effect on HDV replication. Prevention and control of HDV infection requires prevention of HBV transmission through hepatitis B immunization, blood safety, injection safety, and harm-reduction services. $^{12}$ 


\section{HEPATITIS E}

Hepatitis $\mathrm{E}$ is a liver disease caused by HEV. HEV is a small RNA virus with a positive-sense and single-stranded RNA genome. ${ }^{14}$ The virus has at least 4 different types: genotypes 1, 2, 3, and 4 . Genotypes 1 and 2 have only been found in humans. Genotype 3 and 4 viruses circulate in several animals, including pigs, wild boars, and deer without causing any disease. They occasionally infect humans. The virus is shed into stools of infected persons. It then enters human body through the intestine. It is transmitted mainly through contaminated drinking water. Usually the infection is self-limiting. It will resolves within 2-6 weeks. Occasionally, acute liver failure will develop which can lead to mortality. Fulminant hepatitis occurs more frequently when hepatitis E occurs during pregnancy. For immune comprised people, HEV is known to cause chronic infection. 7,14

Hepatitis E infection is found worldwide. This disease is common in resource-limited countries with limited access to essential water, sanitation, hygiene, and health services. In these areas, this disease occurs both as outbreaks and as sporadic cases. ${ }^{15}$ Outbreaks usually follow periods of fecal contamination of drinking water supplies. It might affect several hundred to several thousand people. In these areas, an estimated 20 million infections and 3.3 million acute cases occur annually worldwide, with an estimated 56,600 deaths. ${ }^{7,15}$ In areas with better sanitation and water supply, hepatitis $E$ disease is infrequent with only occasional sporadic cases. ${ }^{16}$ Most of these cases are caused by genotype 3 virus. These cases are caused by infection with virus originating from animals, usually through ingestion of undercooked animal meat, including animal liver. They are not related to contamination of water or other foods. ${ }^{7}$
Definitive diagnosis of hepatitis $E$ infection is usually based on the detection of specific antibodies to HEV. Additional tests include PCR detection of HEV RNA in blood and/or stool. There is no specific treatment capable of altering the course of acute hepatitis $\mathrm{E}$. Immunosuppressed people with chronic hepatitis $\mathrm{E}$ might benefit from specific treatment using ribavirin. A recombinant subunit vaccine to prevent $\mathrm{HEV}$ infection has been registered in China. However, it has not been approved in other countries yet. $^{7,17}$

\section{WHO STRATEGY FOR VIRAL HEPATITIS CONTROL}

WHO has stated that ending viral hepatitis epidemics as a major public health threat is feasible with tools and approaches currently available and those in the pipeline (Table 2). Interventions include vaccines, prevention of mother-to-child transmission of HBV, injection safety, blood and surgical safety, harm reduction for people who inject drugs, and drug treatments. To control viral hepatitis, a continuum of hepatitis services are needed, including reducing vulnerability, preventing and diagnosing infection, linking people to health services, and providing treatment and chronic care (Fig. 1). The goal of WHO is to achieve $90 \%$ reduction for new cases of chronic hepatitis $B$ and $C$ infection and $65 \%$ reduction for mortality from viral hepatitis. To achieve such goal, WHO has set seven service coverage targets that need to be achieved (Table 3). WHO urges countries to develop practicable ambitious national goals and targets by taking country context into consideration, including the nature and dynamics of country viral hepatitis epidemics, populations affected, structure and capacity of the health care and community systems, and resources that can be mobilized.

Table 2. WHO interventions

\begin{tabular}{|c|c|}
\hline Interventions & Comment \\
\hline Vaccines & Effective vaccines are available for preventing $\mathrm{HAV}, \mathrm{HBV}$ and $\mathrm{HEV}^{*}$ \\
\hline $\begin{array}{l}\text { Prevention of mother-to-child } \\
\text { transmission of HBV }\end{array}$ & Antenatal testing, the use of antiviral drugs, and timely HBV birth-dose vaccination \\
\hline $\begin{array}{l}\text { Injection, blood and surgical } \\
\text { safety }\end{array}$ & $\begin{array}{l}\text { Universal precautions for all invasive medical interventions, promotion of injection safety measures, } \\
\text { securing the safe supply of blood products }\end{array}$ \\
\hline $\begin{array}{l}\text { Harm reduction for people who } \\
\text { inject drugs }\end{array}$ & Ensuring access to sterile injecting equipment and effective drug dependence treatment \\
\hline Treatment & $\begin{array}{l}\text { Antiviral drugs for HBV and HCV. New oral, well-tolerated medicines for HCV with a cure rates of over } 90 \% \text {. } \\
\text { Oral, well-tolerated medicines for HBV which can effectively suppress viral replication, although this } \\
\text { treatments needs to be lifelong }\end{array}$ \\
\hline
\end{tabular}

"Approved in China only.

HAV, hepatitis A virus; HBV, hepatitis B virus; $H E V$, hepatitis E virus; $H C V$, hepatitis $C$ virus. 

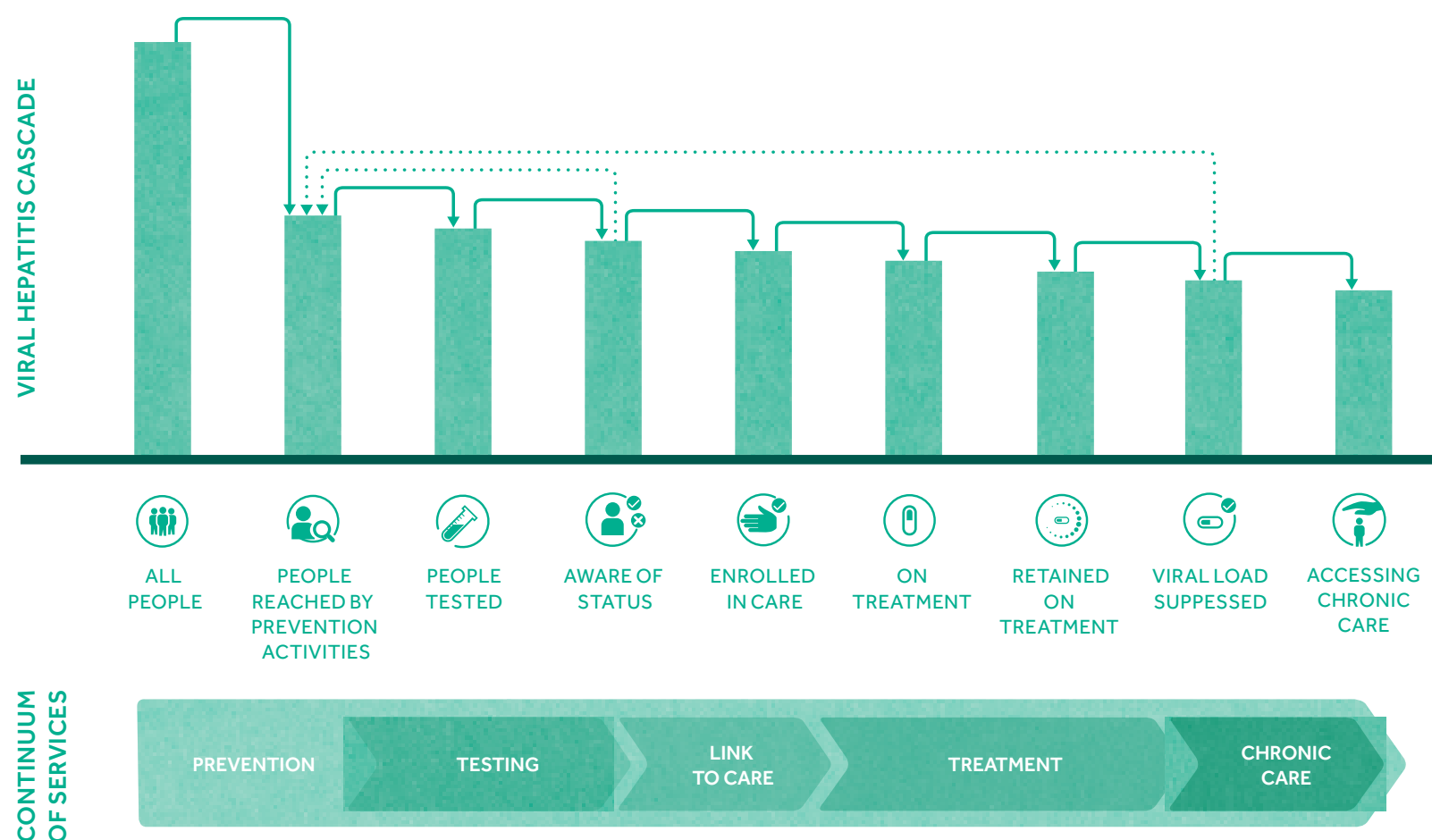

Figure 1. The continuum of viral hepatitis services and the retention cascade (Adopted from GLOBAL HEALTH SECTOR STRATEGY ON VIRAL HEPATITIS 2016-2021).

Table 3. WHO targets

\begin{tabular}{|c|c|c|}
\hline TARGET AREA & 2020 TARGETS & 2030 TARGETS \\
\hline $\begin{array}{l}\text { Incidence: New cases of chronic viral hepatitis B } \\
\text { and C infections }\end{array}$ & $\begin{array}{l}30 \% \text { reduction (equivalent to } 1 \% \\
\text { prevalence of HBsAg among children) }\end{array}$ & $\begin{array}{l}90 \% \text { reduction (equivalent to } 0.1 \% \\
\text { prevalence of HBsAg among children) }\end{array}$ \\
\hline Mortality: Viral hepatitis B and C deaths & $10 \%$ reduction & $65 \%$ reduction \\
\hline $\begin{array}{l}\text { Hepatitis B virus vaccination: childhood vaccine } \\
\text { coverage (third dose coverage) }\end{array}$ & $90 \%$ & $90 \%$ \\
\hline $\begin{array}{l}\text { Prevention of hepatitis B virus mother-to-child } \\
\text { transmission: hepatitis B virus birth-dose } \\
\text { vaccination coverage or other approach to } \\
\text { prevent mother-to-child transmission }\end{array}$ & $50 \%$ & $90 \%$ \\
\hline Blood safety & $\begin{array}{l}\text { 95\% of donations screened in a quality } \\
\text { assured manner }\end{array}$ & $\begin{array}{l}100 \% \text { of donations are screened in a } \\
\text { quality assured manner }\end{array}$ \\
\hline $\begin{array}{l}\text { Safe injections: percentage of injections } \\
\text { administered with safety-engineered devices in } \\
\text { and out of health facilities }\end{array}$ & $50 \%$ & $90 \%$ \\
\hline $\begin{array}{l}\text { Harm reduction: number of sterile needles and } \\
\text { syringes provided per person who injects drugs } \\
\text { per year }\end{array}$ & 200 & 300 \\
\hline Viral hepatitis $B$ and $C$ diagnosis & $30 \%$ & $90 \%$ \\
\hline Viral hepatitis B and C treatment & $\begin{array}{l}5 \text { million people will be receiving } \\
\text { hepatitis B virus treatment } \\
3 \text { million people have received hepatitis } \\
\text { C virus treatment }\end{array}$ & $\begin{array}{l}\text { 80\% of eligible persons with chronic } \\
\text { hepatitis B virus infection treated } \\
80 \% \text { of eligible persons with chronic } \\
\text { hepatitis C virus infection treated }\end{array}$ \\
\hline
\end{tabular}


Table 4. Current national strategy to monitor viral hepatitis in South Korea (year 2016)

\begin{tabular}{|c|c|c|c|}
\hline & Hepatitis A & Hepatitis B & Hepatitis C \\
\hline Classification by the law & Group 1 & Group 2 & Designated $\rightarrow$ Group $3^{*}$ \\
\hline Monitoring of cases & All cases of acute hepatitis A & All cases of acute hepatitis B & $\begin{array}{l}\text { Sentinel surveillance of newly identified } \\
\text { hepatitis C infection } \rightarrow \text { All cases* }\end{array}$ \\
\hline National effort & $\begin{array}{l}\text { National vaccination program } \\
\text { for children }\end{array}$ & $\begin{array}{l}\text { National vaccination program for } \\
\text { children } \\
\text { National prenatal hepatitis B } \\
\text { prevention program }\end{array}$ & None \\
\hline
\end{tabular}

"Changed in year 2016.

Table 5. Current national organization involved in viral hepatitis control in South Korea (year 2016)

\begin{tabular}{|c|c|c|c|}
\hline & Hepatitis A & Hepatitis B & Hepatitis C \\
\hline $\begin{array}{l}\text { Division of infectious disease } \\
\text { surveillance }\end{array}$ & $\begin{array}{l}\text { Epidemiological investigation for } \\
\text { outbreak }\end{array}$ & & $\begin{array}{l}\text { Epidemiological investigation for } \\
\text { outbreak }\end{array}$ \\
\hline $\begin{array}{l}\text { Division of infectious disease } \\
\text { control }\end{array}$ & $\begin{array}{l}\text { Analysis of all reported cases of } \\
\text { acute hepatitis A }\end{array}$ & $\begin{array}{l}\text { Analysis of all reported cases of } \\
\text { acute hepatitis B }\end{array}$ & $\begin{array}{l}\text { Analysis of reported cases of } \\
\text { hepatitis } C \text { from sentinel } \\
\text { surveillance } \rightarrow \text { analysis of all } \\
\text { reported cases }\end{array}$ \\
\hline Division of VPD control and NIP & $\begin{array}{l}\text { National vaccination program for } \\
\text { children }\end{array}$ & $\begin{array}{l}\text { National vaccination program for } \\
\text { children } \\
\text { National prenatal hepatitis B } \\
\text { prevention program }\end{array}$ & \\
\hline $\begin{array}{l}\text { Division of HIV/AIDS and TB } \\
\text { control }\end{array}$ & & & $\begin{array}{l}\text { Genotype evaluation in Outbreak } \\
\text { investigation }\end{array}$ \\
\hline Division of enteric diseases & Research of viral hepatitis & & \\
\hline
\end{tabular}

"Changed in year 2016.

\section{CURRENT STATUS AND STRATEGIES FOR VIRAL HEPATITIS CONTROL IN SOUTH KOREA}

In South Korea, liver disease is a huge public health burden. In 2015 , liver disease was the $8^{\text {th }}$ leading cause of mortality, with 13.4 deaths per 100,000 persons. Moreover, liver cancer is the $2^{\text {nd }}$ leading cause of mortality, with 22.2 deaths per 100,000 persons. Most (70-80\%) liver cancers in South Korea are attributable to hepatitis B and hepatitis C virus. Overall, liver disease is the $4^{\text {th }}$ leading cause of mortality, with 35.6 deaths per 100,000 persons in South Korea. ${ }^{18}$

In South Korea, hepatitis A is classified as group 1 communicable disease (water/foodborne disease) by nationally notifiable infectious diseases. Every case identified is reported to the Centers for Disease Control \& Prevention in South Korea through a mandatory surveillance system. National vaccination program is also implemented for children. Hepatitis B is classified as group 2 communicable disease. National vaccination program for children and national prenatal hepatitis B prevention program are implement- ed. Hepatitis C is classified as 'designated communicable disease', and sentinel surveillance has been done. Selected health care centers report every case of hepatitis $C$ in sentinel surveillance system. Recently, hepatitis $\mathrm{C}$ has been re-classified as group 3 communicable diseases. Mandatory surveillance system for every case is going to be implemented (Table 4). Detailed strategy for hepatitis A, hepatitis B and hepatitis C control in South Korea will be discussed separately in another review. There are no nationwide control programs for HEV or HDV. There are no nationwide programs for chronic hepatitis B patients yet.

One limitation of viral hepatitis control program in South Korea is that there is no control center. Currently, five independent parts at Centers for Disease Control \& Prevention are involved in managing viral hepatitis (Table 5). To achieve the goal of viral hepatitis elimination by 2030 in South Korea, establishment of an independent 'viral hepatitis sector' in Centers for Disease Control \& Prevention is needed to organize and execute comprehensive strategy for the management of viral hepatitis. 


\section{SUMMARY}

Viral hepatitis is a huge burden worldwide as well as in South Korea. In response to WHO call to an action, South Korea must also prepare specific strategy to control viral hepatitis and stop viral hepatitis transmission. In this mini-series, current status and strategy for viral hepatitis are discussed in more details for hepatitis $A$, hepatitis $B$, and hepatitis $C$. This can help us achieve the goal of eliminating viral hepatitis as a public health threat by 2030 in South Korea.

\section{Authors' contribution}

Sinn DH, Cho EJ, Kim JH, Kim DY, Kim YJ, Choi MS have all contributed to the design and the writing of the review.

\section{Financial support}

This research was supposed by a fund (4851-308-260-01) by Research of Korea Centers for Disease Control and Prevention.

\section{Conflicts of Interest}

The authors have no conflicts to disclose.

\section{REFERENCES}

1. Towards elimination of viral hepatitis by 2030. Lancet 2016;388:308.

2. Stanaway JD, Flaxman AD, Naghavi M, Fitzmaurice C, Vos T, Abubakar I, et al. The global burden of viral hepatitis from 1990 to 2013: findings from the Global Burden of Disease Study 2013. Lancet 2016;388:1081-1088.

3. World Health Organization. Sixty-ninth world health assembly provisional agenda item 15.1. Draft global health sector strategies. Viral hepatitis, 2016-2021. <http://apps.who.int/gb/ebwha/pdf_files/ WHA69/A69_32-en.pdf?ua=1>. Accessed 2017. 03.01.

4. Korean Association for the Study of the Liver. KASL clinical practice guidelines: management of chronic hepatitis B. Clin Mol Hepatol 2016;22:18-75.

5. Korean Association for the Study of the Liver. KASL clinical prac- tice guidelines: management of hepatitis C. Clin Mol Hepatol 2016;22:76-139.

6. Matheny SC, Kingery JE. Hepatitis A. Am Fam Physician 2012;86:1027-1034; quiz 1010-1022.

7. Walser E, Ozkan OS, Raza S, Soloway R, Gajula L. Hepatic perfusion as a predictor of mortality after transjugular intrahepatic portosystemic shunt creation in patients with refractory ascites. J Vasc Interv Radiol 2003;14:1251-1257.

8. Halliday ML, Kang LY, Zhou TK, Hu MD, Pan QC, Fu TY, et al. An epidemic of hepatitis $A$ attributable to the ingestion of raw clams in Shanghai, China. J Infect Dis 1991;164:852-859.

9. Severi E, Verhoef L, Thornton L, Guzman-Herrador BR, Faber M, Sundqvist $L$, et al. Large and prolonged food-borne multistate hepatitis A outbreak in Europe associated with consumption of frozen berries, 2013 to 2014. Euro Surveill 2015;20:21192.

10. Moon S, Han JH, Bae GR, Cho E, Kim B. Hepatitis A in Korea from 2011 to 2013: current epidemiologic status and regional distribution. J Korean Med Sci 2016;31:67-72.

11. Choi MS, Sinn DH, Kim SA, Lee YS, Choi W, Paik SW. The clinical and laboratory characteristics of patients with chronic hepatitis B using current or past antiviral therapy in Korea: a multi-center, nation-wide, cross-sectional epidemiologic study. Gut Liver 2012;6:241-248.

12. Rizzetto M. Chronic hepatitis D; at a standstill? Dig Dis 2016;34:303307.

13. Rizzetto M. Hepatitis D virus: introduction and epidemiology. Cold Spring Harb Perspect Med 2015;5:a021576.

14. Jeong SH. Current status of hepatitis e virus infection in Korea. Gut Liver 2011;5:427-431.

15. Hakim MS, Wang W, Bramer WM, Geng J, Huang F, de Man RA, et al. The global burden of hepatitis $E$ outbreaks: a systematic review. Liver Int 2017;37:19-31.

16. Jeong SH, Park BJ, Kim YH, Choi YS, Ahn HS, Han SH, et al. Isolation of hepatitis $\mathrm{E}$ virus genotype 4 from patients with acute cryptogenic hepatitis in Korea. J Clin Virol 2017;89:10-13.

17. Debing Y, Moradpour D, Neyts J, Gouttenoire J. Update on hepatitis E virology: Implications for clinical practice. J Hepatol 2016;65:200-212.

18. Korean Statistical Information Service (KOSIS) <http://kosis.kr/statisticsList/statisticsList_01List.jsp?vwcd=MT_ZTITLE\&parentld=D> Accessed 2017. 03. 01. 